\title{
Alexander's Arabian: Noble Steed or Fantastic Beast?
}

\author{
Miriam A. Bibby
}

\section{Contextualising the equus Arabicus}

This chapter will examine and comment on the meaning of the phrase equum Arabicum in the Augustinian's Account, a document which forms part of the foundation accounts of the Priory of St Andrews, Fife, Scotland. ${ }^{1}$ Originally intended to be part of Foundation Account B (the twelfth-century version of the foundation account of St Andrews), only one eighteenth-century copy of the manuscript of the Augustinian's Account (AA) has survived ${ }^{2}$ (A. A. M. Duncan states that this 1708 edition contains "some manifest errors" 3 ).

Professor Donna Landry suggests that it may be the first record of an importation of an Arab horse not only into Scotland, but into Britain, and that the imports may have started centuries earlier. ${ }^{4}$ The use of the term equus Arabicus to describe an example of the Arabian, or Arab, breed of horse will be discussed later.

In this chapter, I will present evidence for alternative interpretations of the term, placing it within the context of the St Andrews Foundation

\footnotetext{
${ }^{1}$ For the details of these accounts see Simon Taylor, "Appendix One, The St Andrews Foundation Account" and "Appendix Two, The Augustinian's Account," in Medieval St Andrews, Church, Cult, City, ed. Michael Brown and Katie Stevenson (Woodbridge: Boydell and Brewer, 2017), 345-379. For a Latin as well as an English version see Simon Taylor, "Appendix 1, The St Andrews Foundation Account B and The Augustinian's Account," The Place-names of Fife Volume Three, St Andrews and the East Neuk ed. Simon Taylor with G. Márkus (Donington: Shaun Tyas, 2009), 564-615. (Hereafter PNF3)

2 Simon Taylor, "Appendix One," 369.

3 A. A. M. Duncan, "The Foundation of St Andrews Cathedral Priory, 1140," The Scottish Historical Review 84:217 (2005): 1.

4 Donna Landry, "The Bloody Shouldered Arabian and Early Modern English Culture," Criticism 46:1 (2004): 43.
} 
Accounts, which are also known as the Foundation Legends. The aim of the Accounts was to establish (or reinforce) the significance of St Andrews spiritually and temporally, as well as to express, through established ritual, the importance of its relationship with Scottish rulers. Aspects of the Accounts have been incorporated into a more general foundation account, or narrative, for the whole of Scotland. Viewed in this light, the presumed equus Arabicus may provide evidence for broader themes relating to Scottish sovereignty and nationhood.

Exposing these broader themes requires an overview of the Foundation Accounts and the development of St Andrews as the centre of Scottish spirituality, as well as its significance in the wider world of the twelfth century. Following this will be an examination of the equum Arabicum reference as it clearly transmutes across the centuries, from the twelfth century to the present day. I will also engage with issues that arise from the interpretation of the term as Arab (or Arabian) horse, before concluding that it may represent another beast entirely.

\section{The St Andrews Foundation Account}

\section{A. Foundation Accounts $A$ and $B$}

Though much of medieval St Andrews lies in ruins, the result of destruction during the Scottish Reformation, sufficient remains to testify to the town's former importance. ${ }^{5}$ For two centuries, from the fourteenth to the late sixteenth century, St Andrews was a bustling commercial hub dealing in hides and wool, as well as being the center of the cult of St Andrew, Scotland's patron saint. Although its harbor was not large, St Andrews had mercantile connections with the continent, particularly Cologne and Bruges. ${ }^{6}$

Both the shorter Foundation Account (Foundation Account A, or FAA) and the longer version (Foundation Account B, or FAB) recount the origins of St Andrew's connection to the site on the east coast of Scotland that would eventually bear his name. FAB is credited to

\footnotetext{
${ }^{5}$ Michael H. Brown and Katie Stevenson, “'Ancient Magnificence': St Andrews in the Middle Ages: An Introduction," in Medieval St Andrews, Church, Cult, City, ed. Michael Brown and Katie Stevenson (Woodbridge: Boydell and Brewer, 2017), 1.

${ }^{6}$ Elizabeth Ewan, "Living in the Late Medieval Town of St Andrews," in Medieval St Andrews, Church, Cult, City, ed. Michael Brown and Katie Stevenson (Woodbridge: Boydell and Brewer, 2017), 122.
} 
Thana, son of Dubabrach, who is said to have lived in the ninth century. ${ }^{7}$ The account begins by describing how certain relics of St Andrew were saved from Patras by Bishop Regulus before the army of Constantius could seize them and carry them off to Constantinople.

According to FAB, Regulus removed "three fingers of the right hand, and the arm between the elbow and the shoulder, and his kneecap, and one of his teeth" from "the blessed Andrew" as he lay in his sarcophagus.

Simultaneously, the Pictish king Ungus son of Forso (identified as Unust I, $729-761^{\circ}$ ) was preparing to fight Athelstan at the mouth of the River Tyne (a Scottish Tyne, rather than the English one) when a vision of St Andrew appeared to him offering him success if he would provide a home for the saint's bones. ${ }^{10}$ (In some versions of the story Ungus is told to follow the cross of St Andrew, which leads the Picts supernaturally into battle, a parallel with Constantine at the Battle of Milvian Bridge. ${ }^{11}$ ) Ungus agreed, victory inevitably ensued, and shortly afterwards Regulus arrived on the east coast of Scotland with the relics, having been directed north by an angel of God. ${ }^{12}$

The place of his arrival, Muchros ("Pigswood," or possibly Pigpromontory $\left.{ }^{13}\right)$ was renamed Kilrymont, and its association with the Pictish royal family was sealed when a daughter of Ungus, Mouren, was buried there. Ungus gave the land at Kilrymont for a basilica to St Andrew and dedicated it in a ceremony that included walking the land in procession with the bishop before offering a divot of earth on the altar. This highly symbolic act is reminiscent of some rituals still used today when preparing land for building. ${ }^{14}$

The influence of the narrative can be seen in the 1320 creation of The Nation of Scots and the Declaration of Arbroath: "Their [the Scots] high qualities and merits, if they were not otherwise manifest, shine out sufficiently from this: that [...] our lord Jesus Christ [...] called them,

\footnotetext{
7 Simon Taylor, “Appendix One,” in Medieval St Andrews, Church, Cult, City, ed. Michael Brown and Katie Stevenson (Woodbridge: Boydell and Brewer, 2017), 346.

8 Ibidem, 348.

9 A. A. M. Duncan, "The Foundation of St Andrews Cathedral Priory, 1140," 4.

10 Taylor, "Appendix One," 348.

11 FAA, trs. Dauvit Broun, https://openvirtualworlds.org/omeka/items /show/512.

12 Taylor, "Appendix One," 349.

13 Taylor, $P N F 3,584$.

14 Taylor, “Appendix One," 350.
} 
even though settled in the uttermost ends of the earth, almost the first to his holy faith. Nor did he wish to confirm them in that faith by anyone [other] than the most gentle Andrew."15

Thus the connection between Pictish, and later Scottish kingship and the cult of St Andrew was established at an early period, and this informed the Augustinian's Account, the twelfth-century narrative which includes a description of Alexander I's donation at St Andrews.

\section{B. The Augustinian's Account}

Although it refers to events in the reign of Alexander I (r. 1107 - 1124) the Augustinian's Account was not written down until the middle of the twelfth century and is primarily a record of the foundation of the Priory of St Andrews in the year 1140 (or 1144, the year is disputed). Duncan suggests a date of around 1120 for Foundation Account B, ${ }^{16}$ while the Augustinian's Account was most likely the work of Prior Robert, the head of the Augustinian house at St Andrews, who was responsible for the Augustinian house there in 1140, during the reign of David I. Others such as Dauvit Broun suggest a date closer to 1101 for FAB. ${ }^{17}$

As recently as 2009, Simon Taylor commented that the AA had "never been fully edited or translated"18 and the text still offers opportunities for rich discussion. The gift of the equus Arabicus reinforced Alexander's principal donation to the church, which was the highly symbolic "restitution" of the piece of land known as The Boar's Raik which King Hungus/Ungus had first dedicated to God and St Andrew on the arrival of St Andrew's relics. ${ }^{19}$

It is also clear that the royal gift of "liberties and customs" was equally important:

15 A.A.M. Duncan, The Nation of Scots and the Declaration of Arbroath (London: The Historical Association, 1970), 35.

16 Duncan, "The Foundation of St Andrews Cathedral Priory," 4.

17 Dauvit Broun, "The church of St Andrews and its foundation-legend in the early twelfth century: recovering the full text of Version A of the foundation legend," Kings, Clerics and Chronicles in Scotland 500-1297, ed. Simon Taylor (Dublin: Four Courts Press, 2000), 108-14.

18 Taylor, PNF3, 564.

19 Ibidem, 609. 
$\mathrm{Ob}$ cujos etiam donationis monumentum regium equum Arabicum cum proprio freno et sella et scuto et lancea argente, opertum pallio grandi et pretioso praecepit rex usque ad altare adduci; et di praedictis donis, libertatibus et consuetudinibus omnibus regalibus ecclesiam investiri; arma quoque Turchensia diversi generis dedit, quae cum ipsius scuto et sella in memoriam regiae munificientiae usque hodie in ecclesia Sancti Andreae conserve[a]ntur. ${ }^{20}$

[As a royal record of his gift the king ordered to be led to the altar an Arab steed, with its own bridle, saddle, shield and silver lance, and covered with a large, precious cloth; and he ordered the church to be invested with all the aforementioned royal gifts, liberties and customs; he also gave Turkish arms of a different kind, which are still kept in the church of St Andrew, along with its [the steed's] shield and saddle to commemorate royal munificence. $]^{21}$

One suggestion regarding the donation of the "Arab steed" is that it "mirrors, in grander fashion, King Hungus's act of carrying a divot to the altar to symbolise basically the same act." 22 This is a reminder that the Foundation Accounts are richly symbolic, intended to connect monarchy, religion, and nationhood through word, artefact, and deed. They are of political and dynastic significance too, as will be discussed shortly.

\section{St Andrews as the "Second Rome"}

Alexander I was a younger son of Malcolm Canmore and his second wife Margaret, sister of Edgar Atheling of England. Margaret (later Saint Margaret) is often credited, though controversially, with initiating "profound change in Scottish religious life."23 Her confessor and biographer Prior Turgot, later installed by Alexander as Bishop of St Andrews, describes how she established not only houses for pilgrims and the poor to rest in at St Andrews but also ferries to bring them

\footnotetext{
20 Ibidem, 603

${ }^{21}$ Ibidem, 610.

22 Ibidem, 368.

${ }^{23}$ Richard Oram, Kings and Queens of Scotland (Stroud: The History Press, 2017), 55.
} 
across the water, an act which is still remembered in the name Queensferry. ${ }^{24}$

Soon after her death came the first evidence of St Andrews being more than a place of local pilgrimage. ${ }^{25}$ Her sons Alexander and his successor David I are viewed as inheriting her reforming tendencies, and both were responsible for inaugurating religious foundations in Scotland. The Augustinan's Account makes reference to Alexander's special regard for the church ("ecclesiae specialis amatoris"26) and both Alexander and David "emphatically shifted the balance in favor of episcopy." 27

The family had, therefore, a dynastic interest in St Andrews as well as a religious one. It is also clear that David and his son and successor Malcolm IV intended to have St Andrews recognised as the principal seat of religion in Scotland, though this was rejected by the papacy. ${ }^{28} \mathrm{In}$ this light, the reference to Alexander's donations in the AA is a postevent endorsement of the dynasty's commitment to St Andrews.

The family's commitment to St Andrews and the principles of episcopacy also connects directly to the original foundation narrative, since, as Campbell comments, FAA "made the audacious claim that: 'the archiepiscopacy of all Scotia should be exercised from this city where the apostolic see is [and] no bishop ought to be ordained in Scotia without the approval of the elders of this place. For in relation to Rome this is the second. This is the preeminent city of refuge. This is the city of cities of Scotia." 29

\section{The wider medieval context}

\section{A. The impact of the First Crusade}

Interestingly, the gifts donated by Alexander at the altar suggest those of a knight returning home to offer thanks to God. The richly

\footnotetext{
24 Simon Taylor, "From Cinrigh Monai to Civitas Sancti Andree: A Star is Born," in Medieval St Andrews, Church, Cult, City, ed. Michael Brown and Katie Stevenson (Woodbridge: Boydell and Brewer, 2017), 24.

25 Taylor, "From Cinrigh Monai," 24.

26 Taylor, PNF3, 2

27 G.W.S. Barrow, Kingship and Unity: Scotland 1000 - 1306 (London: Arnold, 1981), 66.

28 Barrow, Kingship and Unity, 69.

29 Ian Campbell, "The Idea of St Andrews as the Second Rome Made Manifest," Medieval St Andrews, 35. See also Dauvit Broun, Kings, Clerics and Chronicles, 111.
} 
harnessed horse, the shield, the spear, the Turkish arms are all suggestive of a successful warrior. This may have been a deliberate choice, since the First Crusade had come to a triumphant end in 1099 with the occupation of Jerusalem, and these martial offerings could represent the concept of an ideal Christian warrior king.

However, although known as "the Fierce," King Alexander did not take part in the First Crusade. He gained his nickname only after death, and largely as a result of campaigns against the men of the isles, including some of his own relatives. ${ }^{30}$

Scots certainly participated in the First Crusade, but as individuals rather than an organised force, and there is little, if any evidence, for the participation of the Scottish elite in the First Crusade. ${ }^{31}$ Macquarrie comments that "We can safely say that there was no Scottish presence at the Council of Clermont in November 1095". ${ }^{32}$.However, Edgar Atheling, heir in exile to the English throne and uncle to Alexander, had departed on crusade from Scotland in 1097.33 Though Scotland was a vassal state to England, ${ }^{34}$ the relationship between English and Scottish royalty was close, if not always cordial. There would certainly be an awareness of the Crusade and its possible implications for Scotland, due to the connections between the royal houses, as I will discuss in section III B below.

Macquarrie points out that in 1128 (four years after Alexander's death), Hugh de Patens, the first master of the Knights Templars, introduced the Templars into Scotland and successfully recruited support there for an army. ${ }^{35}$ The force he raised attempted to take Damascus in 1129. David, Alexander's successor, probably wanted to participate in the 1147 crusade but was advised against it, due in part to the reaction of his own people. ${ }^{36}$

In summary, crusading fervour, or fever, was certainly present in Scotland around the times of the First Crusade and of Alexander's

\footnotetext{
30 Oram, Kings and Queens, 59.

31 Alan Macquarrie, The Impact of the Crusading Movement in Scotland 1095 - c. 1560

(Doctoral thesis, University of Edinburgh, 1982), 19.

32 Ibidem.

33 Steven Runciman, A History of the Crusades Volume 1: The First Crusade (London: Penguin Books), 227-228.

34 Oram, Kings and Queens, 62.

35 Macquarrie, Crusading Movement, 20.

36 Ibidem, 20-21.
} 
donation. Since the crusader armies were in conflict with the Seljuk Moslems of Syria, a Turkish people, it is not surprising to read that Alexander donated "arma quoque Turchensia diversi generis." "Turk" would be in general use for centuries to come, and would be used to describe one of the three types of horse designated as "oriental" breeds: the Turk, the Barb, and the Arabian. The later Greeks and Romans used the term "Saracen" (Gk. Sarakènos) to describe the nomads of the vast and little-known desert areas of Syria and Arabia. Later, the term Mussulman for Muslim would be adopted from the Persian musulmān.

What is more unusual is the use of the term arabicum, an early adjectival form of the modern descriptive "Arabic," meaning of the Arabs or of Arabia, used to describe something considered "Arabian." It is particularly unusual in that it refers to a horse, for there is no real evidence for a horse called an "Arabian" at this time. (For the extended argument re this point, see section IVD below.) Nor does the term appear to have been in general use as a descriptive for people in the early twelfth century.

The First Crusade and the establishment of the crusader Kingdom of Jerusalem certainly made the western armies aware of new creatures, cultures, and artefacts. The area that the Romans had known as Arabia Deserta still lived up to its name, a vast expanse of the unknown that might contain miracles and wonders. In the twelfth century, the Kingdom of Jerusalem was a place and time lying at the very border of reality and legend, where the truth behind some of the tales might become manifest. The equus Arabicus hints at exoticism and rarity value. An interesting point raised by Macquarrie, citing Ranald Nicholson, is the idea that "cosmopolitan chivalry," a wider European concept influenced by the crusades, may have been an alternative to "nascent nationalism". ${ }^{37}$ Perhaps in the events at St Andrews in 1120 it is possible to see something of both, with pre-existing elements taken from the Foundation Accounts stressing the traditional side of the ceremony, along with the modern, "cosmopolitan" chivalric donations.

\section{B. Anglo-Scottish relations}

As noted, Margaret, wife of Malcolm III (Máel Coluim mac Donnchada), was the sister of Edgar Atheling and mother to three

${ }^{37}$ Macquarrie, Crusading Movement, 4. 
kings of Scotland, Edgar (r. 1197 - 1107); Alexander I; and David (r. 1124 - 1153). The reigns of all four, from Malcolm to David, were marked by conflict both with England and within the family itself. They were also marked, not surprisingly, by intense political wrangling.

Margaret and Malcolm died within days of each other after an incursion into England by Malcolm and his son and heir Edward. Malcolm and Edward both died as a result of an ambush near Alnwick in Northumberland. ${ }^{38}$ Malcolm's death drew out the differences between Gaelic, or Norse-Gaelic kingship, and the Anglo-Norman tradition. Under Gaelic custom, his heir should now have been the eldest male of the family, his younger brother Domnall mac Donnchada (Donald III). ${ }^{39}$

However, Domnall's nephew, Donnchad, the son of Malcolm III and his first wife, now emerged from the English court as a rival. Supported by an Anglo-Norman army, Donnchad managed to take power briefly before Domnall reclaimed control again. When Edmund, second son of Malcolm and Margaret, as the heir to Canmore attempted a power share with Domnall, it was the signal for William Rufus to give his support to Edgar, a younger son. Open conflict between the younger brothers and Domnall and Edmund ensued, resulting in the imprisonment of Edmund and ultimately the death of Domnall, who was first blinded by order of his nephew David. ${ }^{40}$

After Edgar's rule and death, conflict continued between Alexander and David over Edgar's bequest to his youngest brother of most of southern Scotland. ${ }^{41}$ While Alexander was married to Sibylla, an illegitimate daughter of Henry I, it was David whom Henry favored, and Oram views Alexander as "very much a man of Scotia. It was in the Gaelic heartland of his ancestral kingdom of Tayside that his power was based." 42

It is not too unreasonable to see the potential seeds of independence in the reign of Alexander I. David's reign would be marked by the establishment of Augustinian communities in Scotland, civil war in England (David supported Henry I's daughter Matilda), the

\footnotetext{
38 Oram, Kings and Queens, 55-56.

39 Ibidem, 57.

40 Ibidem, 59.

41 Ibidem, 62.

42 Ibidem, 63.
} 
disastrous Battle of the Standard and the arrival of the Brus family, at David's invitation, in Scotland. It was also marked by a period of economic and political stability, during which "David became more and more a Gaelic king [...] successfully uniting the diverse components of his hybrid domain."43

The Augustinian's Account, written during David's reign by one of his supporters and beneficiaries, can therefore be seen as part of the template for a future Scotland, with all the symbols - or most of them - for Scottish nationhood and kingship with which we are familiar today: the patron saint Andrew, the Saltire, the establishment of a Christian religious center that would be "a second Rome"; plus the arms representing a holy Christian monarch. Prior Robert was also at pains to point out that David confirmed the gifts of Alexander and that at least some of the gifts were still present in the church in his day, ${ }^{44}$ thus stressing the dynastic theme. If there was a symbolic element to the horse, what might that have been?

\section{Menageries in twelfth-century Britain}

The inference of the equus Arabicus is that it is exotic, rare, and costly, a gift fit for a king to give (and receive). In fact, the choice of gifts may have a deeper meaning than is immediately apparent as well as being a reflection of practices elsewhere, and I will discuss that shortly.

For the present, though, it is worth reaffirming that one of the consequences of the First Crusade was to introduce new animals to the west. It is no coincidence that the first true menageries emerged during the twelfth century, and that one of the earliest was that of Henry I at Woodstock, established in 1110 when the king enclosed the existing hunting park with a stone wall and stocked part of it with exotic beasts. ${ }^{45}$

These included lions, lynxes, camels, leopards and even an African porcupine. William of Malmesbury said that Henry begged foreign rulers for animals "with great delight" 46 and he took some of his

\footnotetext{
43 Ibidem, 73.

44 Taylor, PNF3, 603; 610.

45 John Banbury and Peter Jay, "The Normans and the Wall" in Woodstock and the Royal Park: Nine Hundred Years of History, ed. John Banbury et al (Oxford: Woodstock and the Royal Park 900 Years Association, 2010), 7.

46 Woodstock and the Royal Park, 11.
} 
animals with him when he went on royal progress. ${ }^{47}$ It was the start of a tradition that would eventually see a menagerie at the Tower of London, and ultimately, London Zoo.

Interestingly, one nineteenth-century commentator makes a tangential reference to Alexander's Arabian in the context of Henry's penchant for collecting animals: "There is no record of an Arab horse being brought to these islands by a Briton until Alexander, King of Scotland, is known to have presented one to a church in 1121; and his companion, who was a gift from Eastern Europe with some Turkish Armour, was kept at the Royal stud at Gillingham". ${ }^{48}$ The Pipe Roll of Henry I for 1130 is one of the earliest in existence and includes various horse-keeping costs; this may be the source of the tale but I have not inspected it, nor have I found any other author referring to it with regard to the "Arab horse."

There was, of course, no reference to a companion horse in the Augustinian's Account. Cook's comment shows how significantly the story had advanced since the twelfth century, and it is possible to trace its development to this point.

\section{The creation of a legend}

\section{A. "Hys cumly sted off Araby"}

Two fifteenth-century writers confirm the broad details of the Augustinian's Account, including the presence of the equus Arabicus. They are Andrew of Wyntoun and Walter Bower:

Before the Lordys all the Kyng

Gert than to the awtare bryng

Hys cumly sted off Araby,

Sadelyd and brydelyd costlykly,

Coveryd wyth a fayre mantlete

Off precyows and [of] fyne wellvet,

Wyth hys armwrys off Turky,

That pryncys than oysid generaly,

47 Caroline Grigson, Menagerie: the History of Exotic Animals in England 1100 - 1837 (Oxford: Oxford University Press, 2016), 1.

48 Theodore Andrea Cook, History of the English Turf, volume I (London: H. Virtue and Company, 1901), 13. 
And chesyd mast for thare delyte,

Wyth scheld and spere off sylvyr qwhyt,

Wyth mony a precyows fayre jowele,

That now I leve for cause to tell.

- Andrew of Wyntoun, Orygynale Cronykil 49

Anno Domini mcxxii. electus est Robertus, Prior de Scona, in episcopum, ad instantiam regis Alexandri I. Qui terram quæ Cursus Apri dicitur, quæ ab ecclesia Sancti Andreæ ablata fuerat, ex integro restiturt, ea conditione, ut ibi constitueretur religio, ut per regera Alexandrum præordinatum fuerat, et per regium equum Arabicum, cum proprio fræno et sella, opertum pallio grandi et pretioso, cum scuto et lancea argentea, quæ nunc est hasta crucis quæ omnia præcepit rex coram magnatibus terras usque ad altare adduci, et de prædictis libertatibus et consuetudinibus regalibus ecclesiam investiri fecit et fasiri. In the year 1122, Robert, Prior of Scone, was elected Bishop at the behest of King Alexander I. The land known as the Boar's Run, which had been taken from the church of St Andrew, would be restored again as the king had ordered, and at the king's request [or by royal request] a [royal] Arabian horse was led up to the altar, with its own bridle and saddle, covered in a large and valuable cloth, with a shield and a lance of silver, which is now a cross in the church, and the said liberties and customs granted to the church were invested and confirmed.]

- Walter Bower, The Scotichronicon ${ }^{50}$

Both Bower and Wyntoun had connections to St Andrews. Both have embellished the original: Wyntoun's equus Arabicus is now a "cumly sted of Araby"; the cover is a mantlet of fine velvet and the equipage is graced with jewels; Bower notes that the silver spear

\footnotetext{
49 Alexander I, Dictionary of National Biography ed. Aeneas James George Mackay (London: Smith, Elder \& Co, 1885), 261.

${ }^{50}$ Walter Bower, Scotichronicon Book VI, ed. and trans. D.E.R. Watt et al, (Edinburgh: The Mercat Press, 1995), 24. Emphasis mine.
} 
became part of a cross. The Boar's Raik is referenced as "Cursus Apri," the Boar's Run.

Further embellishments and also inaccuracies appear in various nineteenth-century publications. Captain Thomas Brown, for example, in his 1830 work Biographical Sketches and Authentic Anecdotes of Horses and the Allied Species writes: "In the year 1131, Alexander the First presented to the Church of St Andrews, an Arabian horse, furnished with costly trappings, Turkish armor, a quantity of valuable trinkets, and an estate of considerable value. This is the first notice we have of any Arabian steed being brought to the island." 51

Patrick Fraser Tytler describes not only how the king "commanded his favorite horse to be led up to the altar" but also has a squire bring up the "king's body armour, which were studded with jewels, with his spear and his shield of silver" 52 and cites the notorious scholar John Pinkerton as his source. George Craik says it was the "Arabian horse which [the king] was wont to ride, with his bridle, saddle, shield, and silver lance, a magnificent pall or horse-cloth, and other Turkish arms." 53

Thus the equus Arabicus has entered modern texts, as a gift from King Alexander (which Alexander often not specified) to a church (usually not specified) without any of the context of the donation. An event which is said to have occurred in 1121 was recorded around $1140 / 1144$, survives only in a version from 1708 and has been subject to diverse interpretations and additions over the centuries.

\section{Interpretation and appropriation}

One of the most interesting aspects of Alexander's donation is that it is treated as an event that is both unusual and yet unexceptional at the same time - the leading of an animal to an altar. It is also presented in its specifically Scottish context, without reference to any other similar donations elsewhere in Britain, Europe or beyond. Was it so unique?

51 Thomas Brown, Biographical Sketches and Authentic Anecdotes of Horses and the Allied Species (Edinburgh: David Lizar, 1830), 93.

52 Patrick Fraser Tytler, History of Scotland Volume II (Edinburgh: William Tate, 1841), 198.

${ }^{53}$ George Lillie Craik, The History of British Commerce, Volume 1 (London: C. Knight \& Co, 1844), 97. 
In the broader context of horses as elite gifts, it is not exceptional. Anglo-Saxon wills have survived that show the details of tributes of horses as part of the heriot, the heritable part of an estate due from an individual to their lord. ${ }^{54}$ The will of one Ketel includes reference to a heriot of "a helmet, a coat of mail, and a horse with harness and a sword and a spear" to his lord, Archbishop Stigand. ${ }^{55}$

Indeed, the idea of gifting a horse (and arms) seems to have entered certain statutes as an action that was required when entering monastic life. In a commentary on the statutes of Saint Benedict (ca $845 \mathrm{CE}$ ), Hildemar described how young noble boys entering the Abbey of Saint-Martin de Tours "had to give up their horses and their arms, which were left at the saint's tomb, a ceremony meant to renounce the symbolic attributes of the aristocratic laity of the High Middle Ages." 56

Clearly, the gift of a horse from a king to a religious foundation is different in degree and the presentation of a live animal at the altar seems to make it exceptional. Even the most famous gift of an equine to a religious foundation - that of Clovis to the Basilica of St Martin of Tours - is not specified as being directly at the altar, to my knowledge, and it has become most famous for what one scholar describes as "the first joke recorded in Frankish history," 57 that being that when Clovis requested the return of his horse it would not budge from its stable until the king paid the required (and elevated) price for it.

There is a remote echo of this in Alexander's gift, since it has been suggested that the "the 'Arab steed' episode was restoration of that gift [the Boar's Raik], made before magnates, recorded in a narrative which also referred to the election of Robert as bishop, possibly to explain that he could not carry out the foundation," 58 the implication being that Alexander had offered the gift but never actually followed it through, or had possibly taken it back. The horse (and the arms) reinstated, or reaffirmed, his donation. It has also been suggested that the horse was a gift from an ailing or dying man (hence "caused to be led" rather than

54 Dorothy Whitelock, Anglo-Saxon Wills (Cambridge: Cambridge University Press, 2011), passim.

55 Ibidem, 88-89.

56 Danièle Alexandre-Bidon and Didier Lett, Children in the Middle Ages. Fifth-Fifteenth Centuries, trans. Jody Gladding (Notre Dame: University of Notre Dame Press, 1999), 49.

57 Gerberding, quoted in Florin Curta, "Merovingian and Carolingian Gift Giving," Speculum 81:3 (2006): 683.

58 Duncan, The Foundation of St Andrews Cathedral Priory, 7. 
leading it himself) and that this would be an appropriate gift at this stage, with death not far away. ${ }^{59}$

It is interesting to note some unusual enactments elsewhere with horses, one of which is very close in time to Alexander's donation. In 1118 , the embalmed body of the second crusader king of Jerusalem, Baldwin II, was brought into the city on horseback and led through the gate by which Christ himself was supposed to have entered. The date was Palm Sunday. ${ }^{60}$ The impact of this event must have been tremendous, and it was not the first time such an event had been stagemanaged. The young Otto III had entered Cologne as a corpse on horseback over a century earlier. ${ }^{61}$ In both cases, they were events that emphasized the royal and religious in a single act. Alexander's donation may not seem to have quite this level of drama, but it must nonetheless have been an act with vivid visual impact and clearly lasting effect.

The regal aspect of the gift (regium equum Arabicum) has been viewed in two ways. Taylor, in his translation, interprets it as a "royal record" of the entire transaction (that is, what makes it essentially royal is that it comes from a king), ${ }^{62}$ whereas one possible reading of Bower would make it a "royal Arab." 63 What might make it royal relates to the following paragraphs, in which I discuss the evidence for Arabian horses at this time, or rather lack of evidence, for the next section could well have been subtitled the case of the missing Arabians.

\section{Identifying the Arabian horse: the issues}

The modern Arabian horse is internationally acclaimed. It is also one of the most mythologised horse breeds, with some twentieth century enthusiasts making expansive claims for it. The most famous of these enthusiasts is undoubtedly Judith, best known as Lady Wentworth, daughter of Wilfrid and Anne Blunt who travelled in Syria and the Najd collecting horses for their own breeding programs in Cairo and Sussex.

The following quote is typical of Lady Wentworth's beliefs regarding the breed: "The Arabian was known as far back as 5000 B.C.

\footnotetext{
${ }^{59}$ Ibidem.

${ }^{60}$ Max Harris, Christ on a Donkey: Palm Sunday, Triumphal Entries and Blasphemous Pageants (Leeds: Arc Humanities Press, 2019), 21-22.

61 Ibidem, 20.

62 Taylor, PNF3, 610.

${ }^{63}$ Duncan, The Foundation of St Andrews Cathedral Priory, 5.
} 
and was celebrated as a race-horse in Arabia, Egypt and Syria in the fifteenth century and from thence to the thirteenth century, when prices as high as those at Newmarket were being paid by the Sultans for Arabian race-horses." 64 Lady Wentworth also comments "The breed was traditionally wild in Arabia, and the first wild horses are recorded by El Kelbi as having been captured in Yemen by Baz, great-greatgrandson of Noah." 65

While these beliefs have been largely discredited - there is no evidence for the existence of a wild Arabian horse evolving on its own in the desert - Lady Wentworth attempted to establish the term Equus Arabicus (sic) for the breed, as a kind of sub-species of equus Caballus: "The Arabian horse, Equus Arabicus, is the root stock from which all the various Southern varieties are derived. It is the source of all pure breeding and the root stock also of the racing type, being the earliest known racehorse." 66 It was necessary for Wentworth to distinguish the hot-blooded "Southern" Arabian fully from the "coarse-fibred, phlegmatic, thick-haired, thick-skinned, ram-headed, slow" "Northern type." 67 Her beliefs regarding horses reflected her concepts of class, race, and purity.

Arguably, the term equus Arabicus does relate to "Arabia" rather than "Arab." Were the equus Arabicus of the AA intended to mean "the horse of the Arabs," or Arab horse, one might expect to see "equum Arabum" in the text. ${ }^{68}$ The issue is that modern historians, including equine historians dedicated to researching the breed, have been hard-pressed to find evidence of an Arabian horse in antiquity or even medieval times. The Greeks and Romans knew of no breed of horse called "an Arabian"; Hyland, for instance, while still holding to her belief that "there are various indications that the Arabian horse, though going by

64 Lady Wentworth, “The Arabian Thoroughbred," Summerhays' Encyclopaedia for Horsemen, compiled by R.S. Summerhays (London: Frederick Warne, 1966), 11.

65 Ibidem, 12.

${ }^{66}$ Lady Wentworth, Horses of Britain (London: Collins, 1947), 9.

67 Ibidem, 8.

${ }^{68} \mathrm{I}$ am indebted to Jürg Gassmann for making this clear by using the term in his Leeds IMC 2019 presentation, which preceded my own. For a critical analysis of some of the issues relating to Arabian horse influence see Jürg Gassmann, "East meets West: Mounted Encounters in Early and High Mediaeval Europe" in Acta Periodica Duellatorum, 75-107, available at de Gruyter Open Access. DOI 10.1515/apd-20170003 . 
other names, had already developed by Roman times [...], some quote Strabo as saying there were no horses in Arabia then," 69 also points out with scepticism the arguments of the "purists" who "like to say that he rose phoenix-like from the deserts of Arabia. Other more sensible theories admit to mystery, and though discounted by modernists I find Prof. Ridgway's theory of the Libyan ancestry for the modern Arabian very attractive. I believe the movement was to Arabia, rather than from Arabia." 70

Many of the writers referencing Alexander's equus Arabicus stress that it was the first reference to an Arabian horse in Britain. There would be no further reference to a possible Arabian horse (other than Wyntoun's "cumly sted of Araby" until the late sixteenth century when a mysterious stallion was imported via Constantinople from "a parte of Arabia called Angelica" and referenced in one of the editions of Gervase Markham's famous book $A$ discource of horsmanshippe. Interestingly, Markham makes reference to an "olde writing of a Muncks, written in parchement" relating to a story from the Iliad in which Achilles rode on an "Arabian Courser," perhaps hinting at an embellished memory of the Augustinian's Account. ${ }^{71}$ If the importation of Arabians (assuming they existed in an identifiable form) had been going on for centuries and the term equus Arabicus was used to describe them, why does the term only appear, apparently, in the fortuitous survival of the Augustinian's Account? The next use of the term equus Arabicus to genuinely indicate an Arabian horse that $\mathrm{I}$ have found is in Turkish-Arabic-French dictionaries of the eighteenth century.

The investigation is not assisted by the haphazard use of the term Arabian. With regard to the royal studs of medieval England, for instance, all too often horse imports are described in extremely general terms, without specific references: "the Carthaginians introduced oriental blood, and possibly Spanish; in the Muslim and Norman era much Barb and Arabian blood entered." 72 Earlier, post Norman conquest: "There would also have been Syrian strains and some

\footnotetext{
69 Ann Hyland, Equus: The Horse in the Roman World (London: B.T. Batsford, 1990), 24.

70 Ibidem.

${ }^{71}$ Gervase Markham, A Discovrse of Horsemanshippe (London: Richard Smith, 1593), https://quod.lib.umich.edu/e/eebo/A06916.0001.001/1:4?rgn=div1;view=fulltext;q1 = arabian (accessed on 01.01.2020).

72 Ann Hyland, The Warborse 1250 - 1600 (Stroud: Sutton Publishing, 1998), 22.
} 
purebred Arabians as Moorish officers came from the Damascus Caliphate."73 R.H.C Davis comments that "Though there is no specific evidence before the thirteenth century, it is inconceivable that the Normans did not acquire Barb and Arabian horses [via Sicily, once they had conquered it]." 74 Davis does cite some further evidence in a quote from the Song of Antioch: "the Arab people were accursed of God - "but what horses they have and what destriers of price!"'75

The existence of an Arabian in medieval and early modern times is largely based on assumption and inference. Here too, the influence of Lady Wentworth can be witnessed: "Lady Wentworth, while doing sterling work, and using Mantuan archives, nevertheless frequently assumes all orientals to be Arabians." 76 The work of previous generations still vexes that of modern researchers, and the implications of this are recognized by only a few within the field of equine history.

The latest DNA research is not particularly enlightening on the origins of the Arabian horse. There is "increasing affinity to Sassanid Persian horses detected in the genomes of European and Asian horses after the seventh or ninth century, this suggests that the ByzantineSassanid wars and the early Islamic conquests significantly impacted breeding and exchange." 77 This was also the time period when "the horse phenotype was also significantly reshaped, especially for locomotion, speed capacity, and morpho-anatomy. Whether this partly or fully reflects the direct influence of Arabian lines require further tests." ${ }^{\prime 78}$ The search for the Arabian is still the dominant trope. It is also suggested that the newly "shaped" horses could have been disseminated through Arab conquests; but so, arguably, they could by Viking trade routes from the ninth century onwards, in eastern Europe and the north. What then would make them Arabian?

\footnotetext{
73 Ann Hyland, The Horse in the Middle Ages (Stroud: Sutton Publishing, 1999), 14.

${ }^{74}$ R. H. C. Davis, The Medieval W arborse (London: Thames \& Hudson, 1989), 59.

75 Ibidem, 58.

76 Ann Hyland, The Warhorse, 54.

${ }^{77}$ Fages et al, "Tracking Five Millennia of Horse Management with Extensive Ancient Genome Time Series,” Cell (2019), https://doi.org/10.1016/j.cell. 2019.03.049, 7.

78 Ibidem, 11.
} 


\section{Medieval cathedrals: religious places, magical spaces}

\section{$A$. The anticipation of the miraculous}

I have focussed on the Foundation Accounts as creating a narrative not only for St Andrews but also for Scotland. They are miraculous accounts because medieval populations expected miracles and wonders in their churches and cathedrals. Aspects of Alexander's donation hint at miraculous events elsewhere, particularly the donation of the silver spear. This has echoes in a well-known incident during the crusades, in which a pilgrim named Peter Bartholomew, who was accompanying the army, had several visions of St Andrew both during the siege of Antioch and after its capture in 1098.

St Andrew exhorted Peter to go to the church of St Peter, where he would find the lance with which Christ was injured while he hung from the cross. It took several visits from the saint to convince Peter, who eventually told Raymond of Toulouse, and it was Peter himself who discovered the lance after the floor of the church was dug up. The tale was greeted with scepticism by some, but when Bartholomew had another visitation from St Andrew, who successfully predicted an imminent victory over the Turks, Peter's visions were vindicated. ${ }^{79}$

\section{B. Animals at the altar}

While evidence for horses presented at the altar currently seems to be scarce, ${ }^{80}$ there is some documentation relating to the presentation of other live animals such as deer. A book of songs, called The Bishopric Garland, or Durbam Minstrel, includes a song lamenting the death of Sir Robert de Neville, Lord of Raby in 1282, and recalling how he offered a stag at the high altar of Durham Abbey on Holy-rood-day. The event commemorating his death was highly ritualised and accompanied by a

\footnotetext{
79 Anthony Bridge, The Crusades (London: Granada, 1980), 96 - 100; August. C. Krey, The First Crusade: The Accounts of Eyewitnesses and Participants (Princeton: 1921), 174-76. Sourced from: https://sourcebooks.fordham.edu/source/gesta-cde.asp (accessed on 01.01.2020).

${ }^{80} \mathrm{I}$ am indebted to Anastasija Ropa for alerting me to the work of Jonathan Jarrett on Catalan wills and cartularies. While I have only investigated this superficially, it would appear that there may be interesting and relevant case studies for viewing the presentation of equids to religious foundations as part of a wider European phenomenon.
} 
particular song: "LAMENTATION on the death of Sir Robert de Nevill, Lord of Raby in 1282; alludeing to an ancient custom, of offering a stag at the high altar of Durham-abbey on Holy-rood day, accompanied with the winding of horns. WEL-a-wa, salys hornes blaw, Holy-rode this day; Nou is he ded and lies law, Was wont to blaw them ay." 81 The "Wailaway" marks it as a standard lamenting form, and the fact that he who used to blow the hunting horn is now "ded and lies law" while the same horns are blown in his memory is reminiscent of the medieval concept of Fortune's Wheel and the fact that the slayer is now the slain, the hunter has become the victim.

The Sporting magazine or monthly calender of the turf, the chase and every other diversion interesting to the man of pleasure, enterprise and spirit of 1809 recalls the offering of a buck and a doe at St Paul's Cathedral by Sir William le Baud and his family from 1375 onwards, a gift to the Dean and Canons in exchange for the use of 12 or 22 acres of their land:

The buck and doe were offered alive at the high altar of St. Paul's Cathedral, with very particular ceremonies, as follows:- The doe was offered on January $25^{\text {th }}$, the day of the Conversion of St. Paul; and the buck, June 29th the day of the Commemoration of St. Paul.-The buck and doe were brought on these several days, by one or more of the sitting servants of the family, and at the hour of procession, and through the midst thereof, were offered at the high altar in front of the dean and chapter in full robes and wearing roses on their heads. ${ }^{82}$

Deer seem to have played a particularly interesting and complex role in rites and ritual that continued from prehistoric into Christian times. John Clark has noted the ritual significance of the "hobby stag" in medieval times, a role with which horses are more generally associated in the form of the hobby horse, or 'obby 'oss. ${ }^{83}$ This swapping and sharing of functions has linguistic parallels too, in the

81 Sir Cuthbert Sharpe, The Bishoprick Garland, Or a collection of Legends, Songs, Ballads, \&u. Belonging to the County of Durham (London: Nichols, and Baldwin \& Cradock, 1834), 2.

82 Sporting magazine or monthly calender of the turf, the chase and every other diversion interesting to the man of pleasure, enterprise and spirit, 34:118. 1809. (Uncredited item).

83 John Clark, "Playing the stag' in Medieval Middlesex? A perforated antler from South Mimms Castle - parallels and possibilities," in Deer and People, ed. Karis Baker, Ruth Carden and Richard Madgwick (Oxford: Windgather Press, 2015), 208-215. 
Anglo-Saxon "deor," meaning a herd or group animal rather than specifically a deer. In Scotland, the term "stagg," of Norse origin, could refer to a horse or bull as well as an adult deer, or even a young animal of one of these species.

Given that linguistic and functional flexibility existed regarding species, it is perhaps unsafe to attempt to identify an animal on the basis of a single reference. Furthermore, while the form "equus Arabicus" looks familiar, since it is reminiscent of the binomial nomenclature standardized by Linnaeus in the eighteenth century, there is no reason to assume that it had the same purpose in the twelfth century.

\section{Conclusion: the missing mythological link?}

Was Alexander's Arabian, assuming it genuinely did exist, a horse at all? It is strange that it has no antecedents and no real descendants, in either a literal or a linguistic sense, at least for several centuries. ${ }^{84} \mathrm{I}$ suggest an alternative reading of equus Arabicus as literally a horse of Arabia which might render the translation of that part of the account: "As a royal record of his gift, the king ordered to be led to the altar a horse of Arabia, with its own bridle, a saddle, a shield and a silver lance, and covered with a large, precious cloth."

While a saddle and bridle are normally associated directly with a horse, shields, lances and swords are human equipment. The modern Italian term "freno" can mean "brake" as well as bridle, as in the brake of a car. The only thing we can be certain that "goes with" the equus Arabicus is in fact, the "freno" - its own bridle: equum Arabicum cum proprio freno, which indicates restraint of some kind.

If not an actual equine, what would a "horse of Arabia" be? The most likely option would be an Arabian oryx, since certain oryx species (they are, of course, the hippotrages) are often described as horseantelopes. ${ }^{85}$ This brings us to the final piece of the puzzle necessary to

84 There is a reference to "destriers [...] arrabiois" in Cligés by Chrétien de Troyes which requires further investigation, but it is possibly contextually related to alchemical theory. I am grateful to Amelie Blackwell for assisting me in finding an Old French version of the term.

$85 \mathrm{I}$ am indebted to Hylke Hettema for advising me that in Arabic the word that is closest to the Hebrew re'em (unicorn) is r'im, رد meaning a pearly antelope. http://lexicon. quranic-research.net/index.html p. 1004. 
create a foundation account for Scotland - the unicorn, complete with its restraining collar in the form of a royal crown.

As Wilma George and Brunsdon Yapp write in their book The Naming of the Beasts: Natural History in the Medieval Bestiary,

Unicornis has featured widely as a mythical animal and has given rise to many fantasies. There has been much speculation about its identity, but the oryx must be the favourite. The oryx is a "horse-antelope", with the build of the horse and the cloven hoof of the antelope. In Africa and Arabia there are several species of oryx [...]. The horns are soft in the young oryx and often get damaged and deformed during growth. The result can be the reduction of one horn to a curly insignificant stump. Thus, the oryx becomes the unicorn [...]. What is surprising about the bestiaries is that most illustrations depict unicornis more or less as an Arabian oryx that has lost one horn: some even show the asymmetry that would result from turning the two-horned oryx into the unicorn. ${ }^{86}$

It might be argued that since Alexander has no particular association with the Crusades, the arrival of an animal like an Arabian oryx has no logical explanation. The same could be true for the Turkish arms, however, and would also be true of an Arabian horse, which in any case would have no logical requirement to resemble a modern Arabian horse. ${ }^{87}$ The gifts were acquired from somewhere, by someone, and it was the king who presented them. There is much that is unexplained about the gifts, not least Prior Robert's understated commentary about the event. Yet, after all, the main dish was the granting of the Boar's Raik - the equus Arabicus and trappings were the "royal record" of that gift, adopting Taylor's explanation.

\footnotetext{
86 Wilma George and Brunsdon Yapp, Naming of the Beasts: Natural History in the Medieval Bestiary (London: Duckworth \&Co, 1990), 87.

87 DNA research currently places the creation of the modern Arabian horse within the last 200 years: https://www.sciencedirect.com/science/article/abs/pii/S187114130900 3849 (Accessed 19.02.2020). For the most recent research into the Arabian/Arab horse as an Orientalist creation, see Christoph Lange, "The making and remaking of the Arabian horse - from the Arab Bedouin horse to the modern Straight Egyptian," in Horse Breeds and Human Society, eds. Kristen Guest and Monica Mattfeld (Oxford and New York: Routledge 2020), 234-250.
} 
The reasons for the adoption of the unicorn as Scotland's national animal are still largely unknown, although various suggestions have been put forward. What is known is that it was first adopted into the Coat of Arms in the days of William the Lion, grandson of David I and great-nephew of Alexander I. ${ }^{88} \mathrm{Had}$ great-uncle Alexander's mysterious equus Arabicus morphed into the unicorn of popular myth, with its cloven hooves and oryx-like tail? Or was it simply a model to display the rich trappings and armor, some of which Prior Robert said were still on show in the church, something like the palmesels (donkeys on wheels) which were "led" 89 to altars in European churches on Palm Sunday, certainly from the eleventh century onwards and probably earlier?90 900 years later, Alexander's intriguing Arabian still provokes questions.

Nearly four centuries after Alexander's mysterious equus Arabicus made its appearance at St Andrews, the Italian traveller Ludovico di Varthema saw and commented upon two "unicorns" at Mecca, in what he describes as the "temple" there:

Delli unicorni che si trovano appresso il tempio della Mecca, animali rarissimi.

Dall'altra banda del detto tempio è una corte murata, nella qual vedemmo duoi unicorni: e li si mostrano per cosa maravigliosa, come nel vero è cosa da prenderne admirazione. E sono fatti in questo modo: il maggiore è fatto come un poledro di trenta mesi, e ha un corno nella fronte di lunghezza cerca tre braccia; l'altro unicorno era minore, come saria un poledro d'un anno, e ha un corno lungo circa quattro palmi. Il color del detto animale è come un cavallo sasinato scuro, e ha la testa come un cervo e il collo non molto lungo, con alcune crine rare e corte che pendono da una banda, e ha le gambe sottili e lunghe come il capriolo, e il suo piede è un poco fesso davanti e l'unghia è caprina, e ha molti peli di drieto delle gambe, li qual son tanti che fa parer questo animal molto feroce: ma la sua ferocità è coperta da una mansuetudine che in sé dimostra.

\footnotetext{
88 Although this is widely available in popular accounts, especially online, I have yet to find a confirmation of it in an academic account.

${ }^{89}$ Harris, Christ on a Donkey, 152.

${ }^{90}$ Ibidem, 149.
} 
Questi duoi animali furono presentati al soldano della Mecca come cosa de molto prezio e rara e che si trova in pochi luochi, e furono mandati da uno re di Etiopia, il qual li fece questo presente per far amicizia con lui. ${ }^{91}$

The text of Varthema's journey was published in an English translation by the Hakluyt Society in 1863: In another part of the said temple is an enclosed place in which there are two live unicorns, and these are shown as very remarkable objects, which they certainly are. I will tell you how they are made. The elder is formed like a colt of thirty months old, and he has a horn in the forehead, which horn is about three braccia in length. The other unicorn is like a colt of one year old, and he has a horn of about four palmi long. The colour of the said animal resembles that of a dark bay horse, and his head resembles that of a stag; his neck is not very long, and he has some thin and short hair which hangs on one side; his legs are slender and lean like those of a goat; the foot is a little cloven in the fore part, and long and goat-like, and there are some hairs on the hind part of the said legs. Truly this monster must be a very fierce and solitary animal. These two animals were presented to the Sultan of Mecca as the finest things that could be found in the world at the present day, and as the richest treasure ever sent by a king of Ethiopia, that is, by a Moorish king. He made this present in order to secure an alliance with the said Sultan of Mecca. ${ }^{92}$

This is on the whole an accurate translation, apart from the description "dark bay"; "Il color del detto animale è come un cavallo sasinato scuro" would be better translated as "the colour of the said animal is like that of a dark stone coloured horse." The extensive notes provided by George Percy Badger for the Hakluyt edition are also of interest. Among other information he provides the contemporary British measurements of the Venetian braccia (25.08 - 26.87 inches) and the palmo (3.937 inches), while adding the cautionary note that they may not have been the same in di Varthema's day. ${ }^{93}$ Noting that

\footnotetext{
91 Full text in Italian available from www.gingkoedizioni.it/litinerario-di-ludovico-devarthema/. Accessed 16.08.20.

92 John Winter Jones (trs.), The Travels of Ludovico di Varthema in Egypt, Syria, Arabia Deserta and Arabia Felix, in Persia, India, and Ethiopia (The Hakluyt Society: London, 1863), 46-49.

93 Ibidem, 48
} 
Burton had suggested they were possibly "african antelopes, which a lusus naturae had deprived of their second horn," Badger comments:

I was inclined, a first sight, to coincide in this opinion, and to conclude that Varthema saw merely two anomalous specimens of the Oryx, by no means an uncommon quadruped on the north-east coast of Africa, judging from the quantity of its horns brought to Aden by the Somalis. ${ }^{94}$

However, Badger then apparently takes a different view, that they "were living representatives of a species of the antelope family, the existence of which is very generally doubted." 95 There then follows an overview of some similar tales, including those of Pliny relating to unicorns, as well as some of the contemporary debate on the animals, leading Badger to the somewhat astonishing conclusion that:

I am still disposed, nevertheless, to rely on the credibility of Varthema, and to believe that he saw at Meccah two ordinary specimens of the famous unicorn, an animal which further research in the unexplored parts of Central Africa, or among the mountains of Thibet, may yet bring to light. ${ }^{96}$

It is a pity perhaps that time has not yet provided a living example of the "famous unicorn"!

\section{References}

Alexandre-Bidon, and Didier Lett. Children in the Middle Ages. FifthFifteenth Centuries, trans. Jody Gladding. Notre Dame: University of Notre Dame Press, 1999.

Baker, Karis Baker, Ruth Carden and Richard Madgwick. Deer and People. Oxford: Windgather Press, 2015.

Banbury, J, et al, eds. Woodstock and the Royal Park: Nine Hundred Years of History. Oxford: Woodstock and the Royal Park 900 Years Association, 2010.

Barrow, G.W.S. Kingship and Unity: Scotland 1000 - 1306. London: Arnold, 1981.

\footnotetext{
94 Ibidem, 46.

95 Ibidem, 47

96 Ibidem, 48
} 
Bower, Walter. Scotichronicon Book VI, ed. and trans. D.E.R. Watt et al. Edinburgh: The Mercat Press, 1995.

Bridge, Anthony. The Crusades. London: Granada, 1980.

Broun, Dauvit. "The church of St Andrews and its foundation-legend in the early twelfth century: recovering the full text of Version A of the foundation legend." In Kings, Clerics and Chronicles in Scotland 5001297: Essays in Honour of Marjorie Ogilvie Anderson, ed. Simon Taylor, 108-14. Dublin: Four Courts Press, 2000.

Brown, Michael H. and Katie Stevenson. “"Ancient Magnificence': St Andrews in the Middle Ages: An Introduction." In Medieval St Andrews, Church, Cult, City, ed. Michael Brown and Katie Stevenson, 1-19. Woodbridge: The Boydell Press, 2017.

Brown, Michael H. and Katie Stevenson, eds. Medieval St Andrews, Church, Cult, City. Woodbridge: The Boydell Press, 2017.

Brown, Thomas. Biographical Sketches and Authentic Anecdotes of Horses and the Allied Species. Edinburgh: David Lizar, 1830.

Campbell, Ian. "The Idea of St Andrews as the Second Rome Made Manifest." In Medieval St Andrews, Church, Cult, City, ed. Michael Brown and Katie Stevenson, 35 - 50. Woodbridge: The Boydell Press, 2017.

Clark, John. "'Playing the stag' in Medieval Middlesex? A perforated antler from South Mimms Castle - parallels and possibilities." In Deer and People, eds. Karis Baker, Ruth Carden and Richard Madgwick, 208-215. Oxford: Windgather Press, 2015.

Cook, Theodore Andrea. History of the English Turf, volume I. London: H. Virtue and Company, 1901.

Craik, George Lillie. The History of British Commerce, Volume 1. London: C. Knight \& Co, 1844.

Curta, Florin. "Merovingian and Carolingian Gift Giving." Speculum 81:3 (2006): 671-699.

Davis, R.H.C. The Medieval Warhorse. London: Thames \& Hudson, 1989. Duncan, A. A. M. "The Foundation of St Andrews Cathedral Priory, 1140." The Scottish Historical Review Volume 84:217 (2005): 1-37.

- - The Nation of Scots and the Declaration of Arbroath. London: The Historical Association, 1970.

Ewan, Elizabeth. "Living in the Late Medieval Town of St Andrews." In Medieval St Andrews, Church, Cult, City, ed. Michael Brown and Katie Stevenson, 177-140. Woodbridge: The Boydell Press, 2017. 
Fages, Antoine et al. "Tracking Five Millennia of Horse Management with Extensive Ancient Genome Time Series." Cell. 2019. https://doi.org/10.1016/j.cell.2019.03.049, 7.

Gassmann, Jürg. "East Meets West: Mounted Encounters in Early and High Mediaeval Europe." Acta Periodica Duellatorum, 75-107. Available at de Gruyter Open Access. DOI 10.1515/apd-2017-0003.

George, Wilma, and Brunsdon Yapp. The Naming of the Beasts: Natural History in the Medieval Bestiary. London: Duckworth \& Co, 1990.

Głażewska, Iwona. "Speculations on the origin of the Arabian horse breed." Livestock Science 129:1-3 (2010): 49-55.

www.sciencedirect.com/science/article/abs/pii/S187114130900384

9. Accessed online 19.02.2020

Grigson, Caroline. Menagerie: the History of Exotic Animals in England 1100-1837. Oxford: Oxford University Press, 2016.

Harris, Max. Christ on a Donkey: Palm Sunday, Triumphal Entries and Blasphemous Pageants. Leeds: Arc Humanities Press, 2019.

Hyland, Ann. Equus: The Horse in the Roman World. London: B.T. Batsford, 1990.

—. The Warhorse 1250 - 1600. Stroud: Sutton Publishing, 1998.

- . The Horse in the Middle Ages. Stroud: Sutton Publishing, 1999.

Krey, August C. The First Crusade: The Accounts of Eyewitnesses and Participants. Princeton, 1921.

https:// sourcebooks.fordham.edu/source/gesta-cde.asp.

Landry, Donna. "The Bloody Shouldered Arabian and Early Modern English Culture." Criticism 46:1 (2004): 41-69.

Lange, Christoph. "The making and remaking of the Arabian horse from the Arab Bedouin horse to the modern Straight Egyptian." In Horse Breeds and Human Society, ed. Kristen Guest and Monica Mattfeld, 234-250. Oxford and New York: Routledge 2020.

Mackay, Aeneas James George Mackay. "Alexander I." In Dictionary of National Biography. London: Smith, Elder \& Co, 1885.

Markham, Gervase. A Discourse of Horsemanshippe. Wherein the breeding and ryding Horses for service, in a breefe manner is more methodically sette downe then hath been heretofore. With a more easie and direct course for the ignorant, to attaine to the same arte or knowledge. Also the manner to chuse, trayne, ryde and dyet, both Huntinghorses, and Running-horses: with all the secretes thereto belonging discouered. London: Richard Smith, 1593. 
https://quod.lib.umich.edu/e/eebo/A06916.0001.001/1:4?rgn=div $1 ; \mathrm{view}=$ fulltext; $1=$ arabian. Accessed online 01.01.2020

Macquarrie, Alan. The Impact of the Crusading Movement in Scotland 1095 - c. 1560. University of Edinburgh Doctoral Thesis, 1982. www.medievalists.net/2014/02/impact-crusading-movementscotland-1095-c-1560/.

Oram, Richard. Kings and Queens of Scotland. Stroud: History Press, 2017. Angelo Paratico, 5 July 2017.

www.gingkoedizioni.it/litinerario-di-ludovico-de-varthema/.

Runciman, Steven. A History of the Crusades Volume 1: The First Crusade. London: Penguin Books, 1991.

Sharpe, Sir Cuthbert. The Bishoprick Garland, Or a collection of Legends, Songs, Ballads, Soc. Belonging to the County of Durham. London: Nichols, and Baldwin \& Cradock, 1834.

Sporting magazine or monthly calendar of the turf, the chase and every other diversion interesting to the man of pleasure, enterprise and spirit. Vol. 34, 118, 1809. (Uncredited item.)

Taylor, Simon. "From Cinrigh Monai to Civitas Sancti Andree: A Star is Born." In Medieval St Andrews, Church, Cult, City, ed. Michael Brown and Katie Stevenson, 20-34. Woodbridge: The Boydell Press, 2017.

-. "Appendix 1, The St Andrews Foundation Account B and The Augustinian's Account." In The Place-names of Fife Volume Three, St Andrews and the East Neuk, ed. Simon Taylor with G. Márkus, 564615. Donington: Shaun Tyas, 2009.

Tytler, Patrick Fraser. History of Scotland Volume II. Edinburgh: William Tate, 1841.

Wentworth, Judith. Horses of Britain. London: Collins, 1947.

—. "The Arabian Thoroughbred." In Summerbays' Encyclopaedia for Horsemen, compiled R.S. Summerhays. London: Frederick Warne, 1966.

Winter Jones, John (trs.). The Travels of Ludovico di Varthema in Egypt, Syria, Arabia Deserta and Arabia Felix, in Persia, India, and Ethiopia. The Hakluyt Society: London, 1863.

Whitelock, Dorothy. Anglo-Saxon Wills. Cambridge: Cambridge University Press, 2011. 